\title{
Evaluation of RANK induced periodontitis in rats previously exposed to Cyclosporine A
}

\author{
Avaliação da RANK na periodontite induzida em ratos previamente expostos à Ciclosporina A \\ Evaluación de RANK en periodontitis inducida en ratas previamente expuestas a Ciclosporina A
}

Received: 01/11/2021 | Reviewed: 01/15/2021 | Accept: 01/18/2021 | Published: 01/2 1/2021

Felipe da Silva Peralta
ORCID: https://orcid.org/0000-0002-1664-4658
Universidade de Taubaté, Brazil
E-mail: felipe.periodontia@ @otmail.com
Lucilene Hernandes Ricardo
ORCID: https://orcid.org/0000-0003-3375-7854
Universidade de Taubaté, Brazil
E-mail: lumello1 @ uol.com.br
Hilson Fernando Resende Nogueira
ORCID: https://orcid.org/0000-0003-4182-3372
Universidade de Taubaté, Brazil
E-mail: hilsonfernando@bol.com.br
Renata Falchete do Prado
ORCID: https://orcid.org/0000-0001-5970-0464
Instituto de Ciência e Tecnologia de São Jose dos Campos, Brazil
E-mail: renatafalchete@ @otmail.com
Richardson Mondego Boaventura
ORCID: https://orcid.org/0000-0003-4647-3340
Universidade Santo Amaro, Brazil
E-mail: rmondegoboaventura @yahoo.com.br
Yeon Jung Kim
ORCID https://orcid.org/0000-0002-5908-2907
Universidade Santo Amaro, Brazil
E-mail: yjkim @prof.unisa.br
Debora Pallos
ORCID https://orcid.org/0000-0001-7426-1041
Universidade Santo Amaro, Brazil
E-mail: dpallos@prof.unisa.br

\begin{abstract}
The aim of this study was to investigate the effect of previous exposure to CsA on the expression of RANK and bone loss in experimental periodontitis induced in rats. Forty rats were divided into four groups as follows: Control (CON); Cyclosporine A (CsA), with daily doses of $10 \mathrm{mg} / \mathrm{Kg}$ of CsA; Ligature (LIG), with a ligature around the upper right second molar on day 30; and Ligature + CsA (CsAL). Sixty days later, the animals were sacrificed and samples removed for histomorphometric and immunohistochemical analysis of bone resorption, bone density and RANK expression. There was no significant influence of bone resorption on the application of CsA. LIG Group (735.88 \pm 121.82) had significantly higher bone resorption $(p=0.01)$ than CON Group (569.13 \pm 89.76$)$, and CsAL Group $(759.38 \pm 198.23)$ also had significantly higher bone resorption $(P=0.001)$ than CsA Group $(410.90 \pm 105.95)$. Bone density in the CsA Group $(87.49 \pm 4.07)$ was lower than that of CON Group $(92.42 \pm 2.27)$ and similar to that of LIG Group $(91.85 \pm 3.91)$. CsAL Group $(79.41 \pm 3.81)$ showed the lowest density compared to the other groups. RANK did not differ between the groups. The prior exposure to CsA had no influence on the expression of RANK or bone resorption.
\end{abstract}

Keywords: Cyclosporine A; Alveolar bone loss; Periodontitis; Osteoporosis; Receptor activator of nuclear factorkappa B.

\section{Resumo}

O objetivo deste estudo foi investigar o efeito da exposição prévia a CsA na expressão de RANK e perda óssea na periodontite experimental induzida em ratos. Quarenta ratos foram divididos em quatro grupos da seguinte forma: Controle (CON); Ciclosporina A (CsA), com doses diárias de $10 \mathrm{mg} / \mathrm{Kg}$ de CsA; Ligadura (LIG), com uma ligadura ao redor do segundo molar superior direito no dia 30; e Ligadura + CsA (CsAL). Sessenta dias depois, os animais foram sacrificados e as amostras removidas para análise histomorfométrica e imuno-histoquímica da reabsorção óssea, densidade óssea e expressão de RANK. Não houve influência significativa da reabsorção óssea na aplicação de CsA. O grupo LIG $(735,88 \pm 121,82)$ apresentou reabsorção óssea significativamente maior $(\mathrm{p}=0,01)$ do que o grupo 
CON $(569,13 \pm 89,76)$, e o grupo CsAL $(759,38 \pm 198,23)$ também apresentou reabsorção óssea significativamente maior $(\mathrm{P}=0,001)$ do que o grupo CsA $(410,90 \pm 105,95)$. A densidade óssea no grupo CsA $(87,49 \pm 4,07)$ foi menor que a do grupo CON $(92,42 \pm 2,27)$ e semelhante à do grupo LIG $(91,85 \pm 3,91)$. O grupo CsAL $(79,41 \pm 3,81)$ apresentou a menor densidade em comparação aos outros grupos. RANK não diferiu entre os grupos. A exposição prévia a CsA não teve influência na expressão de RANK ou reabsorção óssea

Palavra-chave: Ciclosporina A; Perda óssea alveolar; Periodontite; Osteoporose; Ativador de receptores do fator nuclear-kappa B.

\section{Resumen}

El objetivo de este estudio fue investigar el efecto de la exposición previa a CsA en la expresión de RANGO y pérdida ósea en periodontitis experimental inducida en ratas. Cuarenta ratas se dividieron en cuatro grupos de la siguiente manera: Control (CON); Ciclosporina A (CsA), con dosis diarias de $10 \mathrm{mg} / \mathrm{Kg}$ de CsA; Ligadura (LIG), con una ligadura alrededor del segundo molar superior derecho en el día 30; y Ligature + CsA (CsAL). Sesenta días después, se sacrificaron los animales y se extrajeron muestras para análisis histomorfométricos e inmunohistoquímicos de resorción ósea, densidad ósea y expresión de RANGO. No hubo influencia significativa de la resorción ósea en la aplicación de CsA. El grupo LIG (735.88 \pm 121.82$)$ tuvo una resorción ósea significativamente mayor $(\mathrm{p}=0.01)$ que el grupo CON (569.13 \pm 89.76), y el grupo CsAL (759.38 \pm 198.23$)$ también tuvo una resorción ósea significativamente mayor $(\mathrm{P}=0.001)$ que el grupo CsA $(410.90 \pm 105,95)$. La densidad ósea en el grupo CsA (87.49 $\pm 4.07)$ fue menor que la del grupo CON $(92.42 \pm 2.27)$ y similar a la del grupo LIG $(91.85 \pm 3.91)$. El grupo CsAL (79.41 \pm 3.81$)$ mostró la densidad más baja en comparación con los otros grupos. RANGO no difirió entre los grupos. La exposición previa a CsA no tuvo influencia en la expresión de RANGO o resorción ósea.

Palabras clave: Ciclosporina A; Pérdida de hueso alveolar; Periodontitis; Osteoporosis; Receptor activador del factor nuclear kappa-B.

\section{Introduction}

Cyclosporine A (CsA) is widely used as an immunosuppressive drug in patients who received transplants. The drug interferes with the IL-2 synthesis and has inhibitory effects on T-helper lymphocytes. Because of its effectiveness, its use has been extended to other applications in medical therapy, such as treatments for type 1 diabetes mellitus, psoriasis, rheumatoid arthritis, ulcerative colitis, multiple sclerosis and oral erosive liquenplane (Boltchi et al., 1999; Hallmon et al., 1999).

Unwanted side effects associated with the use of CsA were already described in the literature, such as dyslipidemia, neuro and nephron-toxicity, hypertension, gingival overgrowth, osteopenia and osteoporosis. These side effects are associated with the prolonged therapy with high doses and concomitant use with other drugs. However, there is controversy about the effects of CsA on biological events of bone remodeling (Fu et al., 2001; Spolidório et al., 2001; Spolidório et al., 2004; Wada et al., 2006).

The effects of CsA on the alveolar bone in rats showed that there was an inhibitory effect on the alveolar bone absorption after using the drug (Shen et al., 2001). Other studies demonstrated that there was a decrease in the stimulation of alveolar bone formation caused by CsA (Spolidório et al., 2004; Cetinkaya et al., 2006). Likewise, a study with rats of different ages assessed whether the use of CsA or nifedipine affects bone metabolism, showing a decrease in alveolar bone volume caused by CsA and nifedipine alone or in combination, regardless of the age of the animal (Spolidório et al., 2004).

The quantification of the interference of CsA in bone remodeling events regarding the pathogenesis of periodontal disease has been the subject of many studies by using animal models (Fu et al., 1999; Shen et al., 2001; Spolidório et al., 2004, Nassar et al., 2004, Spolidorio et al., 2007, Jayasheela, et al., 2013, da Silva Peralta et al., 2015, Ricardo et al., 2019 ). These studies are all designed for applying CsA at the same time as the induction of periodontal disease. However, by following a different methodology, a study evaluated the influence of previous exposure to CsA on experimental periodontitis induced in rats and showed that CsA had no influence on bone resorption (da Silva Peralta et al., 2015).

In pathogenesis studies, rats have been used as animal model and the biological events associated with the degradation of periodontal tissues have been described in the presence of different molecules and growth factors (Li et al., 2015). Among these molecules, we can cite the activator of nuclear factor Kappa B (RANK) as a biological bone marker. Research on the presence of RANK and RANKL has been carried out in order to correlate these molecules with loss and bone remodeling 
(Souza, \& Lerner, 2013, Arboleya, \& Castañeda 2013, Lin et al., 2014).

Based on these aspects, the objective of this study was to evaluate the influence of previous exposure to CsA on bone resorption and of the presence of RANK on experimental periodontitis induced in rats.

\section{Methods}

\subsection{Experimental design}

This study was conducted in accordance with the standards approved by the Brazilian College of Animal Experiments and submitted to the Animal Research Ethics Committee according to EAEC registry and UNITAU number 0/019/706). Forty adults male Wistar rats (Rattus novergicus, albino variation), ten weeks old and weighing approximately $300 \mathrm{~g}$ were housed in cages and provided with water and food ad libitum. The rats were randomly separated into four groups ( $\mathrm{n}=10$ each): Control group (CON); Cyclosporine A group (CsA), which received administration of $10 \mathrm{mg} / \mathrm{kg}$ of CsA (Sandimmun, Novartis, São Paulo, SP, Brazil) at the start of the experiment; Ligature group (LIG), which received insertion of a cotton ligature around the upper right second molar on day 30 after the beginning of experiment; and Ligature + Cyclosporine A group (CsAL), which received treatment with CsA and insertion of a cotton ligature. Daily doses of CsA were applied by gavage in the animals of CsA and CsAL groups for 60 days. After this period, the animals were sacrificed by cardiac perfusion with $4 \%$ formalin solution after intramuscular anaesthesia and a combination of $13 \mathrm{mg} / \mathrm{kg}$ body weight of xylazine $2 \%$ (Rompum, Bayaer, São Paulo, SP, Brazil) with $33 \mathrm{mg} / \mathrm{kg}$ body weight of ketamine (Francotar, Virbac, Roseira, SP, Brazil). The jaws were removed and analyzed.

\subsection{Analysis of Bone Resorption}

The jaws were decalcified in 10\% EDTA for 30 days. The upper right second molar was mesially sectioned to determine the inclusion part. Next, the resulting parallel sections were embedded in paraffin, with the palatal area being faced to the cutting plane in order to obtain mesio-distal sections. Five semi-serial $(5 \mu \mathrm{m})$ sections were prepared and stained with Mallory tri-chrome dye for assessment of bone tissue at the free surfaces. To analyze the bone resorption, the distance between cemento-enamel junction of the upper right second molar and bone crest was measured by using the software Image Tool for Windows, version 3.0 (Image Tool, San Antonio, Texas, USA) (see Figure 1). 
Figure 1 - Sections of bone tissue showing measurement of bone resorption. cemento-enamel junction (CEJ), Junctional epithelial (JE), bone crest (BC), Connective tissue (C), Root (R) Periodontal ligament (PDL). Mallory trichrome staining at a magnification of $200 x$.

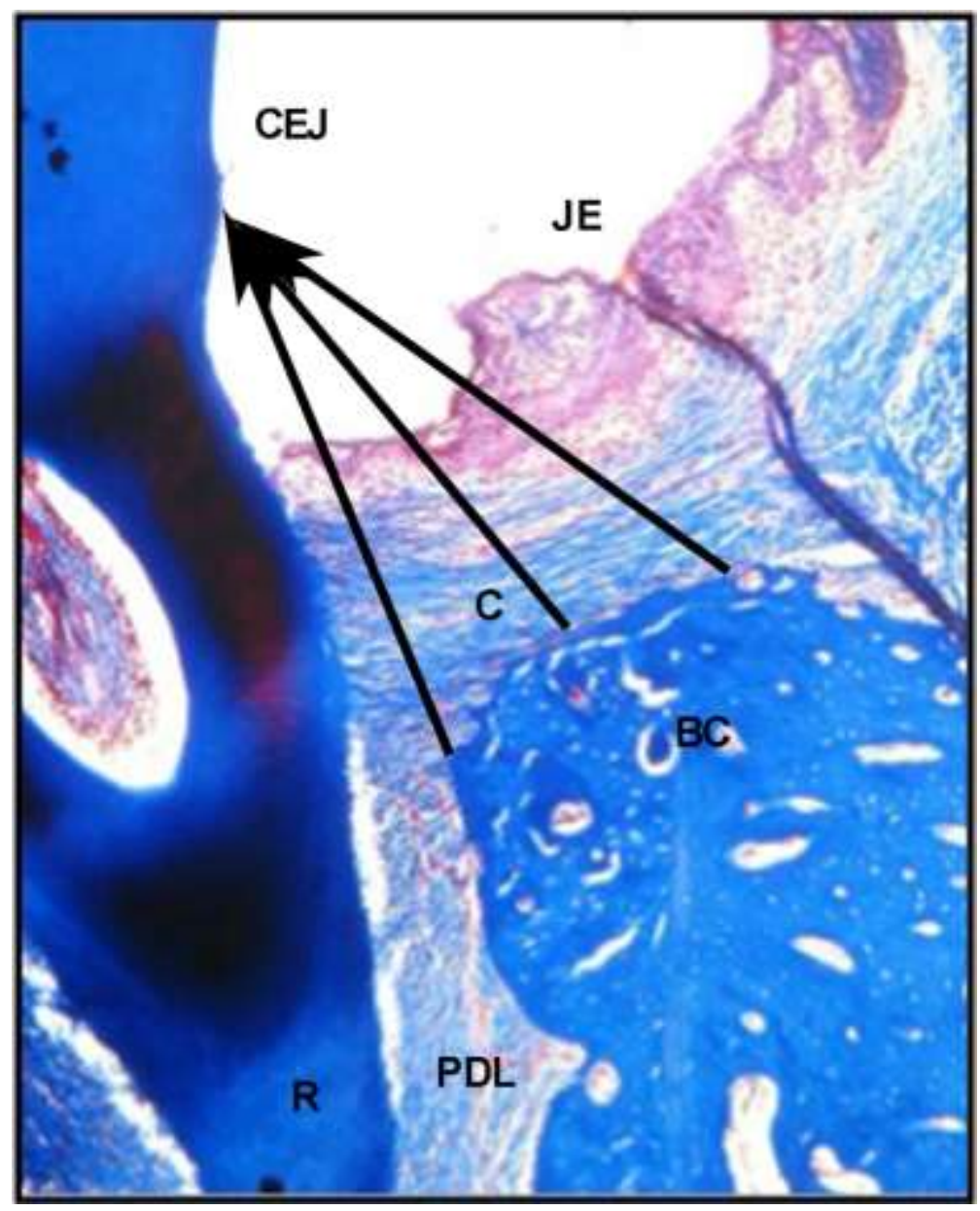

Source: Authors.

\subsection{Analysis of Bone Density}

Bone density was assessed by calculating the ratio of trabecular bone (TB) to medullar area (MA), whereas counting was made by using the software Image J for Windows, version 3.0 (NIH, Bethesda, Maryland, USA). The images were obtained at 200x magnification from the semi-serial sections of $5 \mu \mathrm{m}$ and $60 \mu \mathrm{m}$ interval between each cut.

\subsection{RANK Analysis}

Sections of $3-\mu \mathrm{m}$ thickness were obtained for RANK immunohistochemical staining and anti-RANK antibody (Abcam, Santa Cruz, CA, USA) was used with antigen retrieval, which was performed with 5\% citric acid (Merck Darmstadt, Germany) after incubation for 15 minutes in microwave. Both block of endogenous peroxidase and fixation of primary antibody were performed by using the Universal LSAB kit (Dako, Dako Co, Carpinteria, CA, USA). The reaction was visualized by using 3\% diaminobenzidine (Dako, Dako Co, Carpinteria, CA, USA) and counter-stained with Harris hematoxylin (Merck Darmstadt, Germany). Two observers assessed the presence of markers for RANK with a scoring system as follows: negative marking (-), meaning absence of marker; weak marking (+), meaning that less than $25 \%$ of the cells were labeled; moderate marking $(++)$, meaning that $25 \%$ to $50 \%$ of the cells were labeled; strong marking $(+++)$, meaning that 
more than $50 \%$ of the cells were labeled. All analyses were performed at 400x magnification (Liang et al., 2008) (see Figure 2).

Figure 2 - Section of bone tissue showing immunohistochemical marker of RANK. RANK immunohistochemical staining at a magnification of $400 x$.

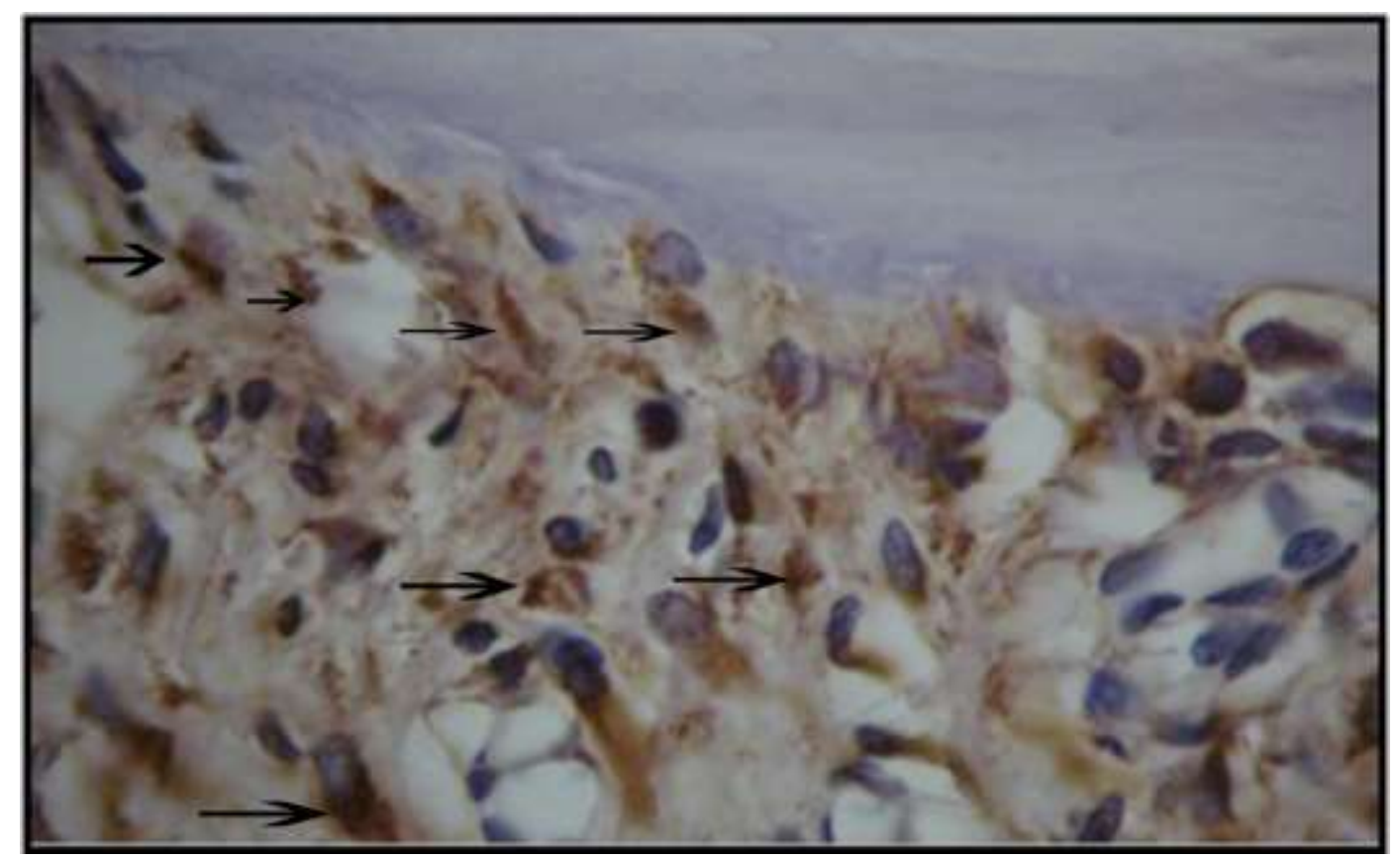

Source: Authors.

\subsection{Statistical Analysis}

The experimental groups were compared for presence of ligature and CsA. Based on the distribution of the mean values observed in each group, the results were analysed by using the software BioStat version 5.0 (Instituto de Desenvolvimento Sustentável Mamiruá, Tefe, Amazonas, Brazil) for non-parametric (Kruskal-Wallis) or parametric (ANOVA/Tukey) tests.

\section{Results}

\subsection{Bone Resorption}

The results regarding bone loss showed differences between the experimental groups $(P=0.01)$. As for palatal bone loss, there was no difference between the LIG $(735.88 \pm 121.82)$ and CsAL (759.38 \pm 198.23$)$ groups, with both having higher values than those of the CON (569.13 \pm 89.76$)$ and CsA $(410.90 \pm 105.95)$ groups (see Figure 3$)$. 
Figure 3 - Analysis of bone resorption (mean $\pm \mathrm{SD}$ ).

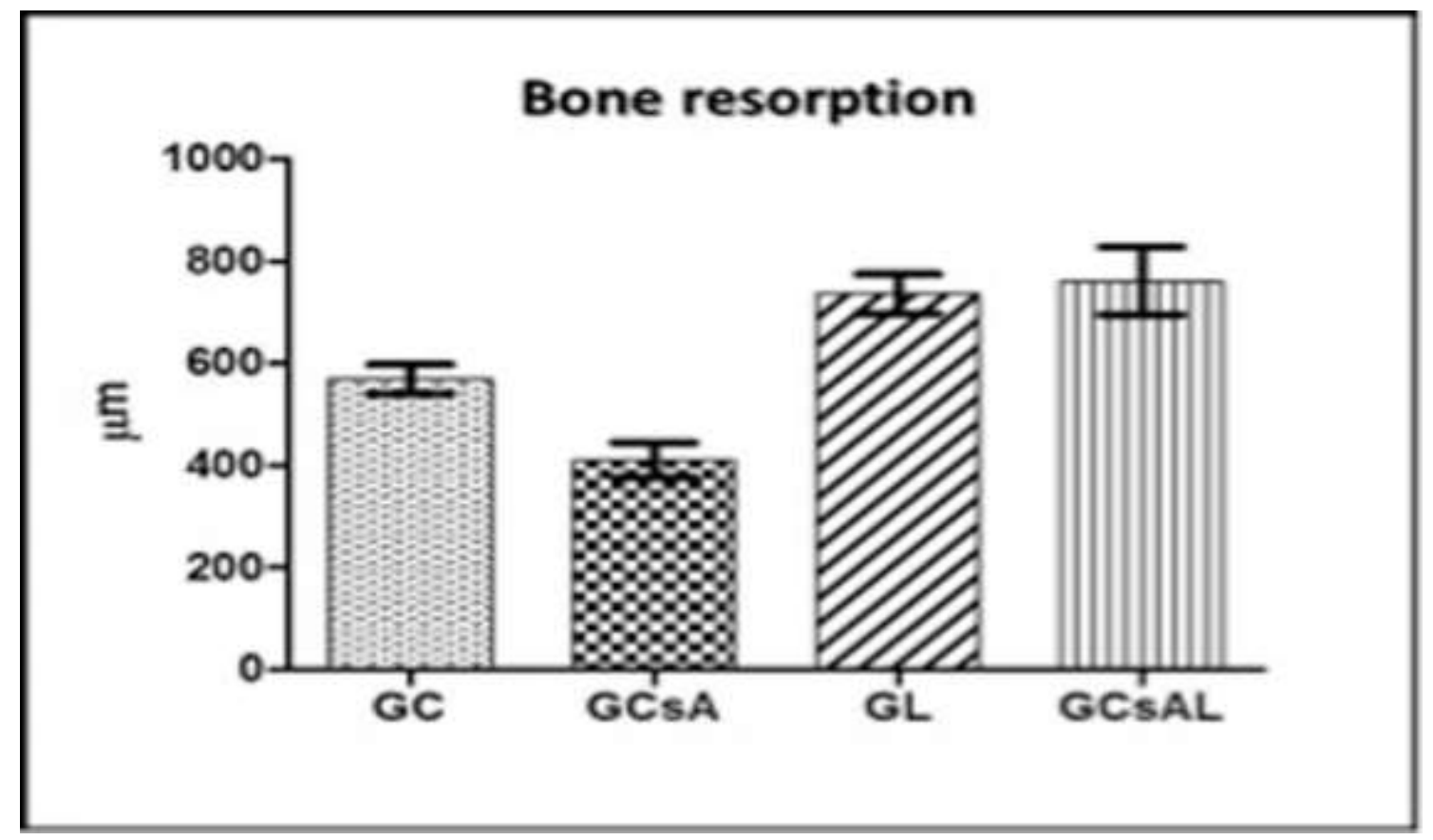

Source: Authors.

Histological section of the jaw fragment containing gingival tissue, tooth and bone tissue was analyzed. The CsA, LIG and CsAL groups presented gingival tissue with increased thickness of the epithelium. In the CON and CsA groups, the junctional epithelium was positioned near the cementoenamel junction, whereas in the LIG and CsAL groups it was positioned near the cement. Periodontal ligament, blood vessels, fibroblasts, fibrocytes and collagen fibers were observed in the bone, as well as marrow spaces and areas of resorption associated with the presence of osteoclasts (see Figure 4). 
Figure 4 - Sections of jaw fragment showing gingival tissue, teeth and bone tissue. Junctional epithelial (JE), oral epithelial thickness (EOE) and connective tissue (CT) were increased in CsA, LIG and CsAL groups compared to CON group. (a) Control group; (b) Cyclosporine A group; (c) Ligature group; (d) Ligature and Cyclosporine A group. Dentin (D), epithelial cement junctional (ECJ), (SOE) sulcular oral epithelium (SOE), periodontal ligament (PL), alveolar bone (AB)

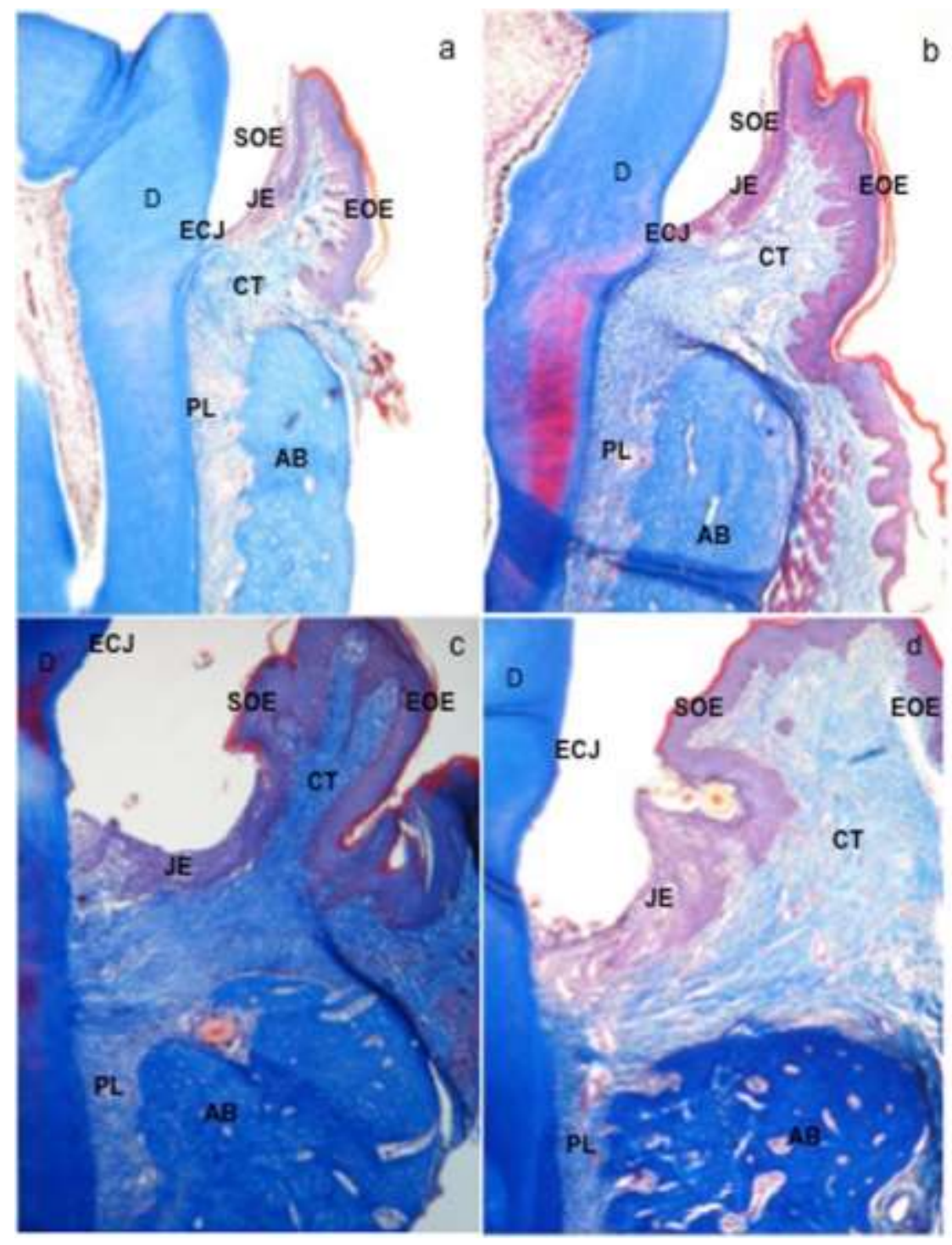

Source: Authors.

\subsection{Bone Density}

The results regarding bone density showed differences between the experimental groups $(P=0.001)$. The relationship between bone marrow and trabecular bone in percentage revealed to be significantly lower in CsA group (87.49 \pm 4.07$)$ than in CON group $(92.42 \pm 2.27)$. There was no difference between the CON and LIG groups $(91.85 \pm 3.91)$, with both having higher values than those of CsA and CsAL groups $(79.41 \pm 3.81)$. In the presence of inflammation, the CsAL group showed a significant decrease compared to the LIG group (see Figure 5). 
Figure 5 - Analysis of bone density (mean \pm SD).

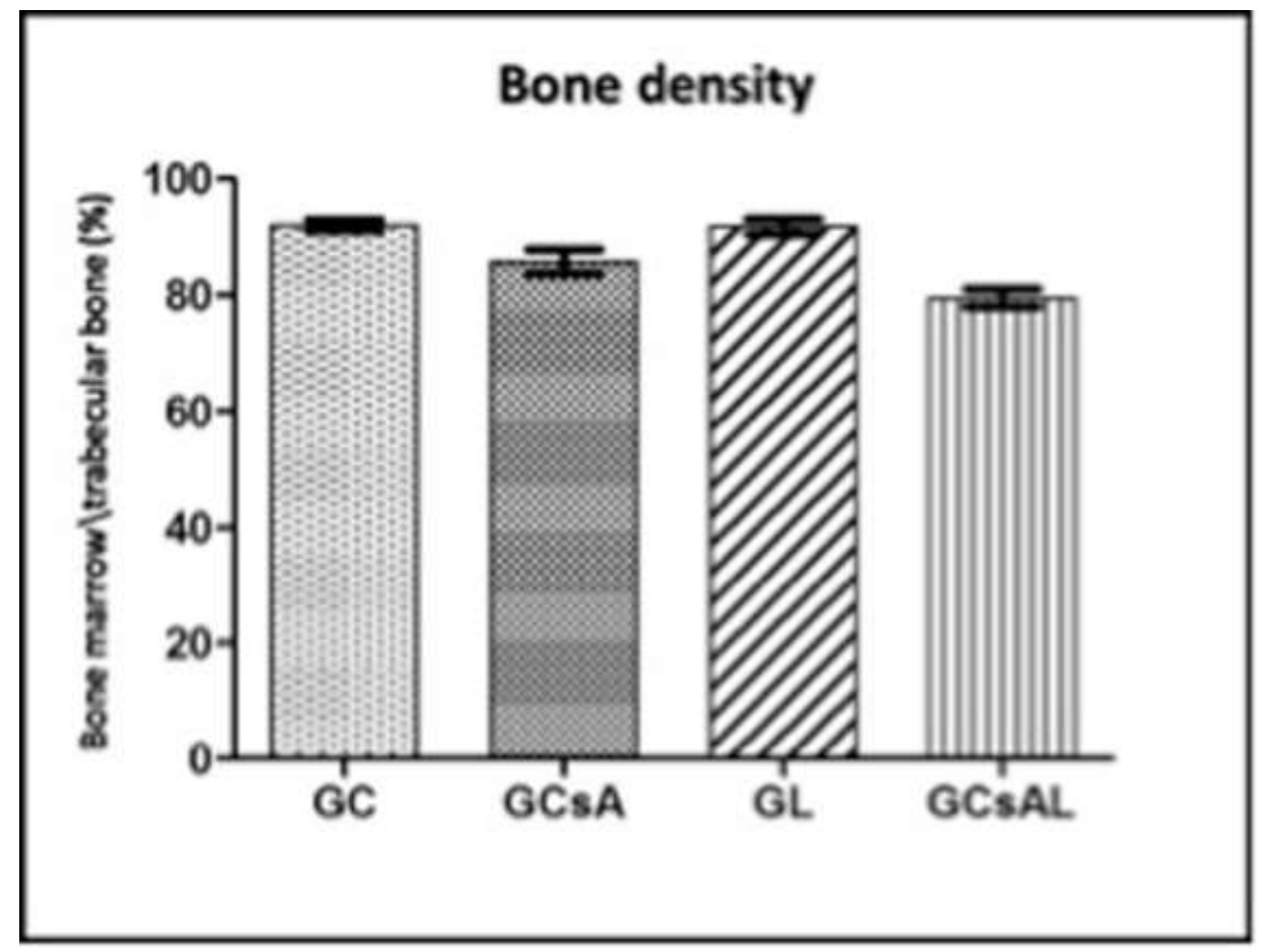

Source: Authors.

\subsection{RANK expression}

The results regarding RANK showed no significant differences between the experimental groups $(P=0.122)$. The RANK for CON group was higher than for the other groups. There was no difference between the CsA, LIG and CsAL groups, with all of them having values lower than that of CON group (see Figure 6). 
Figure 6 - Analysis of the markers of RANK (mean $\pm \mathrm{SD}$ ).

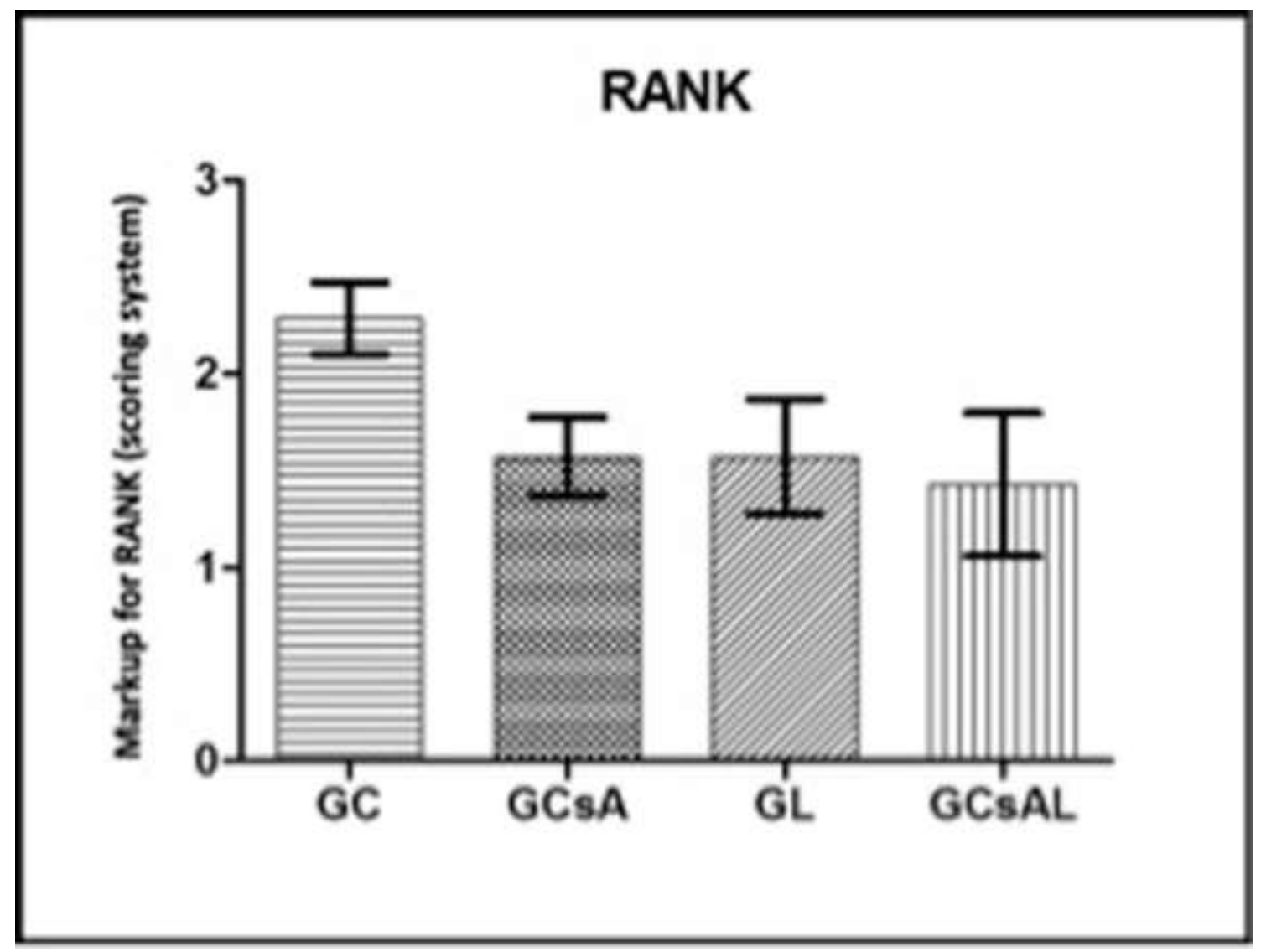

Source: Authors.

\section{Discussion}

This study has investigated bone loss in ligature-induced periodontitis in immunosuppressed rats by using CsA. The interference of CsA with bone remodeling was measured by a different methodology described in most studies for induction of periodontal disease while using medication (Nassar, et al., 2004; Cetinkaya et al., 2006). Changes in the metabolism of bone tissue caused by CsA represent an adverse effect of this drug and may be a possible risk factor for periodontal disease, thus contributing to the beginning, progression and repair of periodontal disease (Liang et al., 2008; Jayasheela et al., 2013).

Bone resorption due to periodontal disease is the result of an imbalance between the actions of osteoclasts and osteoblasts on bone resorption and formation, which might be related to various osteoclastogenesis-stimulating factors (Goodman et al., 2001). In the present study, bone resorption showed higher mean values in the ligature (LIG) and ligature + cyclosporine A (CsAL) groups, suggesting that bone resorption is associated with the induction of periodontal disease in rats. In vitro and in vivo studies reporting that $\mathrm{T}$ and $\mathrm{B}$ lymphocytes express some factors (e.g. TGF- $\beta$ ) which are strongly associated with the beginning of bone resorption in the periodontal disease (Van Dyke, 2007; Nassar et al., 2013).

The administration of cyclosporine A has been associated with imbalance in bone turnover (Fu et al., 1999; Wada et al., 2006), resulting in osteopenia and osteoporosis (Spolidório et al., 2004). A decrease in T lymphocytes differentiation due to the presence of immunosuppressants, such as CsA, has been described to reduce bone resorption (Fu, et al., 1999, Goodman et al., 2001, Nassar et al., 2004) However, in the present study the results suggest that prior exposure to CsA resulted in lower bone density (CsA group) and contributed to increasing the bone resorption associated with periodontal disease (CsAL group). These findings are similar to those reported by Nassar et al. (2009) that found that CsA therapy combined with ligature 
placement decreased the bone area and intensified the imbalance in the alveolar bone homeostasis in a rat model of experimental periodontitis.

Bone remodeling is a biological event regulated by a number of chemical mediators, such as RANK, RANKL, OPG and cytokines produced by bone cells, all playing critical role in the regulation and differentiation of osteoclastic cells (Takayanagi, 2005). Therefore, we can consider that RANK, RANKL and OPG are critical for controlling osteoclast activity, which suggests they play a key function in the progression of bone loss in periodontitis (Takayanagi, 2005). The participation of these cytokines is essential for bone remodeling as they regulate the interaction between $\mathrm{T}$ lymphocytes and dendritic cells. Moreover, they are essential for the development and activation of osteoclasts and bone loss in inflammatory processes. $\mathrm{T}$ lymphocytes also express RANKL and thus they have influence on the recruitment of new osteoclasts, becoming important regulators of bone formation and resorption (Takayanagi, 2005).

In the present study, the expression of RANK showed a divergent behavior. We can consider that the immunosuppression generated by exposure to CsA inhibited the $\mathrm{T}$ lymphocytes differentiation, consequently decreasing the possibility of expression of RANK. Therefore, the control group presented a more homogeneous distribution for this marker. These results are in agreement with findings showing that after exposure to CsA no direct influence on alveolar bone loss was observed, with RANK influencing more significantly the osteoclastogenesis and participating directly in bone remodeling and, consequently, in bone density improvement (Goodman et al., 2001, Kawai et al., 2006).

\section{Final Considerations}

Based on the limits of the present study, the immunosuppression generated by CsA may have influenced the bone density, but not bone resorption and RANK expression in ligature-induced periodontitis in rats. Clinically we can assume that patients who take this type of immunosuppressant (Ciclosporine A) prior to the development of periodontal disease should not have greater bone loss due to the medication. We must always keep in mind the care with periodontal control of these patients.

\section{References}

Arboleya, L., \& Castañeda, S. (2013). Osteoimmunology: the study of the relationship between the immune system and bone tissue. Reumatologia clinica, 9(5), 303-315. https://doi.org/10.1016/j.reuma.2013.02.008.

Boltchi, F. E., Rees, T. D., \& Iacopino, A. M. (1999). Cyclosporine A-induced gingival overgrowth: a comprehensive review. Quintessence international (Berlin, Germany: 1985), 30(11), 775-783.

Cetinkaya, B. O., Acikgoz, G., Keles, G. C., Ayas, B., \& Korkmaz, A. (2006). The effect of cyclosporin A on alveolar bone in rats subjected to experimental periodontal disease. Toxicologic pathology, 34(6), 716-722. https://doi.org/10.1080/01926230600826269

da Silva Peralta, F., Pallos, D., Silva Queiroz, C., \& Ricardo, L. H. (2015). Previous exposure to Cyclosporine A and periodontal breakdown in rats. Archives of oral biology, 60(4), 566-573. https://doi.org/10.1016/j.archoralbio.2015.01.004

Fu, E., Hsieh, Y. D., Nieh, S., Wikesjö, U. M., \& Liu, D. (1999). Effects of cyclosporin A on alveolar bone: an experimental study in the rat. Journal of periodontology, 70(2), 189-194. https://doi.org/10.1902/jop.1999.70.2.189

Fu, E., Hsieh, Y. D., Mao, T. K., \& Shen, E. C. (2001). A histomorphological investigation of the effect of cyclosporin on trabecular bone of the rat mandibular condyle. Archives of oral biology, 46(12), 1105-1110. https://doi.org/10.1016/s0003-9969(01)00080-2

Goodman, G. R., Dissanayake, I. R., Bowman, A. R., Pun, S., Ma, Y., Jee, W. S., Bryer, H. P., \& Epstein, S. (2001). Transforming growth factor-beta administration modifies cyclosporine A-induced bone loss. Bone, 28(6), 583-588. https://doi.org/10.1016/s8756-3282(01)00428-8

Hallmon, W. W., \& Rossmann, J. A. (1999). The role of drugs in the pathogenesis of gingival overgrowth. A collective review of current concepts. Periodontology 2000, 21, 176-196. https://doi.org/10.1111/j.1600-0757.1999.tb00175.x

Jayasheela, M., \& Mehta, D. S. (2013). The role of cyclosporine A on the periodontal tissues. Dental research journal, 10(6), 802-808.

Kawai, T., Matsuyama, T., Hosokawa, Y., Makihira, S., Seki, M., Karimbux, N. Y., Goncalves, R. B., Valverde, P., Dibart, S., Li, Y. P., Miranda, L. A., Ernst, C. W., Izumi, Y., \& Taubman, M. A. (2006). B and T lymphocytes are the primary sources of RANKL in the bone resorptive lesion of periodontal disease. The American journal of pathology, 169(3), 987-998. https://doi.org/10.2353/ajpath.2006.060180 
Research, Society and Development, v. 10, n. 1, e41610111108, 2021

(CC BY 4.0) | ISSN 2525-3409 | DOI: http://dx.doi.org/10.33448/rsd-v10i1.11108

Li, Y., Lu, Z., Zhang, X., Yu, H., Kirkwood, K. L., Lopes-Virella, M. F., \& Huang, Y. (2015). Metabolic syndrome exacerbates inflammation and bone loss in periodontitis. Journal of dental research, 94(2), 362-370. https://doi.org/10.1177/0022034514561658

Liang, L., Yu, J. F., Wang, Y., \& Ding, Y. (2008). Estrogen regulates expression of osteoprotegerin and RANKL in human periodontal ligament cells through estrogen receptor beta. Journal of periodontology, 79(9), 1745-1751. https://doi.org/10.1902/jop.2008.070437

Lin, D., Li, L., Sun, Y., Wang, W., Wang, X., Ye, Y., Chen, X., \& Xu, Y. (2014). IL-17 regulates the expressions of RANKL and OPG in human periodontal ligament cells via TRAF6/TBK1-JNK/NF-אB pathways. Immunology, 144(3), 472-485. Advance online publication. https://doi.org/10.1111/imm.12395

Stanford, T. W., \& Rees, T. D. Acquired immune suppression and other risk factores/indicators for periodontal disease progression. Periodontol 2000. 2003; 32:118-135.

Nassar, C. A., Nassar, P. O., Abi Rached, R. S., Holzhausen, M., Marcantonio, E., Jr, \& Spolidorio, L. C. (2004). Effect of cyclosporin A on alveolar bone homeostasis in a rat periodontitis model. Journal of periodontal research, 39(3), 143-148. https://doi.org/10.1111/j.1600-0765.2004.00739.x

Nassar, P. O., Felipetti, F. A., Nassar, C. A., \& Spolidorio, L. C. (2013). Evaluation of effect of cyclosporine A on the bone tissue with induced periodontal disease to ligature in rats. Transplantation proceedings, 45(2), 778-782. https://doi.org/10.1016/j.transproceed.2012.02.029

Ricardo, L. H., do Prado, R. F., Carvalho, Y. R., da Silva Peralta, F., \& Pallos, D. (2019). Cyclosporine A - Induced gingival overgrowth and proliferating cell nuclear antigen expression in experimental periodontitis. Journal of oral biology and craniofacial research, 9(1), 86-90. https://doi.org/10.1016/j.jobcr.2018.10.004

Shen, E. C., Fu, E., \& Hsieh, Y. D. (2001). Effects of cyclosporin A on dental alveolar bone: a histomorphometric study in rats. Journal of periodontology, 72(5), 659-665. https://doi.org/10.1902/jop.2001.72.5.659

Souza, P. P., \& Lerner, U. H. (2013). The role of cytokines in inflammatory bone loss. Immunological investigations, 42(7), 555-622. https://doi.org/10.3109/08820139.2013.822766

Spahni, A. I., Schawalder, P., Rothen, B., Bosshardt, D. D., Lang, N., \& Stoffel, M. H. (2009). Immunohistochemical localization of RANK, RANKL and OPG in healthy and arthritic canine elbow joints. Veterinary surgery: VS, 38(6), 780-786. https://doi.org/10.1111/j.1532-950X.2009.00566.x

Spolidório, L. C., Merzel, J., Villalba, H., Vargas, P. A., Coletta, R. D., \& Almeida, O. P. (2001). Morphometric evaluation of gingival overgrowth and regression caused by cyclosporin in rats. Journal of periodontal research, 36(6), 384-389. https://doi.org/10.1034/j.1600-0765.2001.360606.x

Spolidorio, L. C., Spolidorio, D. M., \& Holzhausen, M. (2004). Effects of long-term cyclosporin therapy on the periodontium of rats. Journal of periodontal research, 39(4), 257-262. https://doi.org/10.1111/j.1600-0765.2004.00734.x

Spolidorio, L. C., Marcantonio, E., Jr, Spolidorio, D. M., Nassar, C. A., Nassar, P. O., Marcantonio, R. A., \& Rossa, C., Jr (2007). Alendronate therapy in cyclosporine-induced alveolar bone loss in rats. Journal of periodontal research, 42(5), 466-473. https://doi.org/10.1111/j.1600-0765.2007.00970.x

Takayanagi, H. (2005). Inflammatory bone destruction and osteoimmunology. Journal of periodontal research, 40(4), 287-293. https://doi.org/10.1111/j.1600-0765.2005.00814.x

Van Dyke, T. E. (2007). Cellular and molecular susceptibility determinants for periodontitis. Periodontology 2000, 45, 10-13. https://doi.org/10.1111/j.16000757.2007.00228.x

Wada, C., Kataoka, M., Seto, H., Hayashi, N., Kido, J., Shinohara, Y., \& Nagata, T. (2006). High-turnover osteoporosis is induced by cyclosporin A in rats. Journal of bone and mineral metabolism, 24(3), 199-205. https://doi.org/10.1007/s00774-005-0672-x 